NASA TECHNICAL NOTE

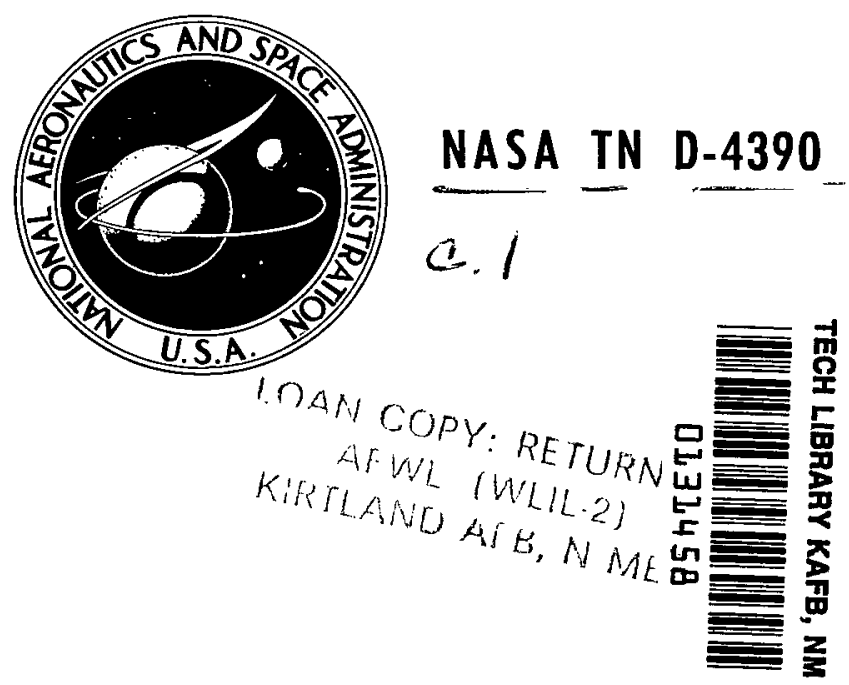

\title{
APPLICATION OF DIRECTIONAL SOLIDIFICATION TO A NASA NICKEL-BASE ALLOY (TAZ-8B)
}

by Jobn C. Freche, William J. Waters, and Richard L. Ashbrook

Lewis Research Center Cleveland, Obio

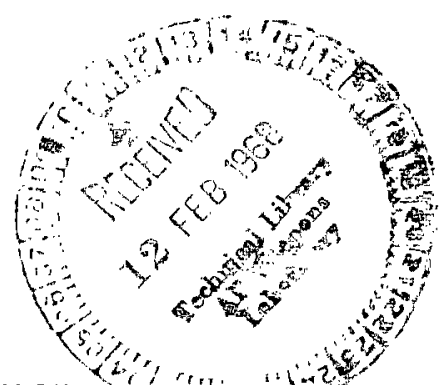

NATIONAL AERONAUTICS AND SPACE ADMINISTRATION - WASHINGTON, DEE - FEBRUARY 1968 
APPLICATION OF DIRECTIONAL SOLIDIFICATION TO A NASA NICKEL-BASE ALLOY (TAZ-8B)

By John C. Freche, William J. Waters, and Richard L. Ashbrook Lewis Research Center Cleveland, Ohio

\author{
NATIONAL AERONAUTICS AND SPACE ADMINISTRATION \\ For sale by the Clearinghouse for Federal Scientific and Technical Information \\ Springfield, Virginia 22151 - CFSTI price $\$ 3.00$
}




\title{
APPLICATION OF DIRECTIONAL SOLIDIFICATION TO A
}

\author{
NASA NICKEL-BASE ALLOY (TAZ-8B) \\ by John C. Freche, William J. Waters, and Richard L. Ashbrook \\ Lewis Research Center
}

\section{SUMMARY}

A nickel-base alloy (TAZ-8B) has been developed which compares favorably in hightemperature strength with known high-strength nickel-base alloys. Although basically a cast material, the alloy also has workability potential.

By applying directional solidification techniques, test specimens were produced with a preferred columnar grain orientation. Grain boundaries transverse to the major stress axis were largely eliminated. Substantial increases in ductility, ultimate tensile strength, and stress-rupture life were obtained with the alloy in the directional polycrystalline condition, as compared with the random polycrystalline condition. For example, the $1400^{\circ} \mathrm{F}\left(1033^{\circ} \mathrm{K}\right)$ tensile elongation, which was 3 percent in the random polycrystalline form, was increased to 6 percent in the directional polycrystalline form. Ultimate tensile strength was similarly raised from $144000 \mathrm{psi}\left(993 \mathrm{MN} / \mathrm{m}^{2}\right)$ to 172000 psi $\left(1185 \mathrm{MN} / \mathrm{m}^{2}\right)$ at this temperature. The $1000-, 100-$, and 10-hour use temperatures at $15000 \mathrm{psi}\left(103.4 \mathrm{MN} / \mathrm{m}^{2}\right)$ are $1785^{\circ}, 1925^{\circ}$, and $2025^{\circ} \mathrm{F}\left(1247^{\circ}, 1325^{\circ}\right.$, and $\left.1380^{\circ} \mathrm{K}\right)$, respectively, in the conventional random polycrystalline form and $1830^{\circ}, 1940^{\circ}$, and $2040^{\circ} \mathrm{F}\left(1272^{\circ}, 1333^{\circ}, 1389^{\circ} \mathrm{K}\right)$ in the directional polycrystalline form.

On the basis of calculated electron-vacancy number, TAZ-8B would not be expected to form sigma phase. Only minor decreases in $1400^{\circ} \mathrm{F}\left(1033^{\circ} \mathrm{K}\right)$ ductility were observed after exposure for 1000 hours at $1600^{\circ} \mathrm{F}\left(1144^{\circ} \mathrm{K}\right)$. Tensile elongation decreased from 3.3 to 2.0 percent for the random polycrystalline material and from 6.5 to 6.0 percent for the directional polycrystalline material.

The application of directional solidification to TAZ-8B resulted in alloy properties which are of interest for potential advanced-gas-turbine-engine applications. 


\section{INTRODUCTION}

Nickel-base alloys continue to be the workhorse materials for the hot components of gas-turbine engines. These components include turbine buckets, stator vanes, transition ducts, afterburner liners, and, in some advanced engines, the later compressor stages as well. A major factor in the evolution of gas-turbine engines has been the continued increase in high-temperature strength and ductility obtainable with nickel-base alloys. Increased high-temperature strength can be translated into higher operating temperatures and improved engine performance. Increased ductility can contribute to improved mechanical and thermal fatigue resistance, both extremely important factors in various turbine components, particularly turbine buckets. Research is in progress at the NASA Lewis Research Center to further extend the high-temperature capability of nickel-base alloys for gas-turbine and other elevated-temperature applications.

Earlier research at Lewis has resulted in several high-strength cast nickel-base alloys (refs. 1 to 7) culminating in the TAZ-8 series (refs. 5 and 7). Both TAZ-8 and TAZ-8A compare favorably in high-temperature strength with some of the strongest commercial nickel-base alloys. TAZ-8A also has excellent high-temperature oxidation resistance (ref. 7). Although these alloys are basically cast materials, they have workability potential. For example, limited unidirectional forging has been done successfully with small test samples (ref. 5), and 0.020-inch (0.0005-m) sheet has been rolled from cast slabs (ref. 7). Because of the interesting properties of these alloys, additional work was indicated to further enhance their high-temperature capability.

The first approach taken was to modify the nominal TAZ-8A composition which was 8 percent tantalum, 6 percent chromium, 6 percent aluminum, 4 percent molybdenum, 4 percent tungsten, 2. 5 percent columbium, 1 percent zirconium, 0.125 percent carbon, 0.004 percent boron, and the balance nickel. Columbium content was reduced to 1.5 percent because data obtained during the development of TAZ-8A (ref. 7) suggested that small reductions in columbium could improve ductility without adversely affecting either oxidation resistance or strength. Also, 5 percent cobalt was added to further stabilize the gamma-prime $\left(\gamma^{\prime}\right)$ phase (ref. 8). The resulting composition is referred to as TAZ-8B.

The second approach was to employ controlled directional solidification techniques with TAZ-8B. At high temperatures a frequent failure mode in cast nickel-base alloys is intercrystalline fracture along grain boundaries transverse to the major stress axis. VerSnyder and Guard have shown that improvements in strength and ductility can be obtained if such boundaries are eliminated (ref. 9). In that study, a normally brittle Ni$\mathrm{Cr}-\mathrm{Al}$ alloy was shown to have both high ductility and longer rupture life when a unidirectional columnar grain structure with preferred orientation was obtained by directional solidification. Also, Piearcey and VerSnyder showed that improvements in high- 
temperature strength and intermediate temperature ductility could be obtained with MARM 200 by directional solidification (ref. 10).

Extensive data were therefore obtained for the TAZ-8B alloy in both the random polycrystalline and directional polycrystalline forms. Rollability was also investigated. Tensile data were obtained to $2200^{\circ} \mathrm{F}\left(1478^{\circ} \mathrm{K}\right)$ and stress-rupture data to $2100^{\circ} \mathrm{F}$ $\left(1422^{\circ} \mathrm{K}\right)$. The results of these studies together with comparisons with an earlier nickel-base alloy in the TAZ-8 series are presented.

\section{EXPERIMENTAL PROCEDURES}

\section{Materials}

The purities in weight percent, as reported by the supplier, of the various alloying elements used are as follows:

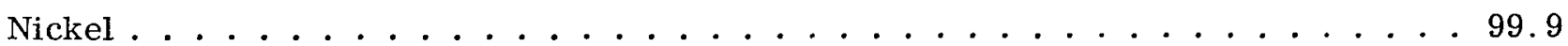

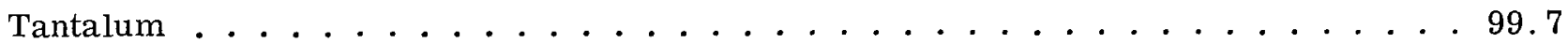

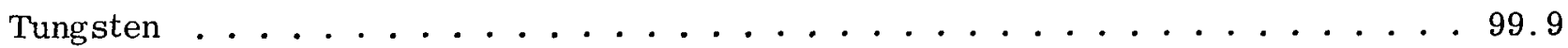

Molybdenum .......................... 99.5

Chromium ........................... . . 99.8

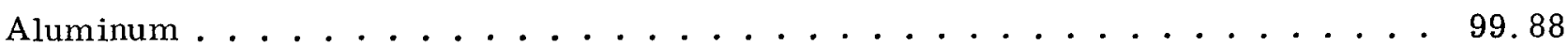

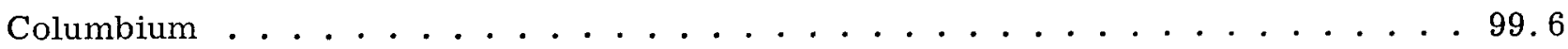

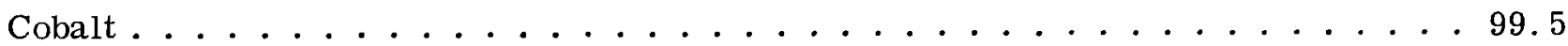

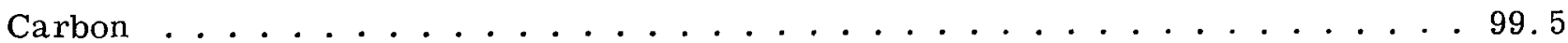

Boron ............................. 99.5

Chemical analyses of typical heats of random polycrystalline TAZ-8B were made by an independent laboratory and are compared with the nominal composition in table I. The analyses indicated that the compositions were close to the nominal composition, except for carbon in one heat. Although a chemical analysis was not obtained for a heat of directional polycrystalline material, no differences in composition from a heat of random

TABLE I. - ALLOY COMPOSITION

\begin{tabular}{|c|c|c|c|c|c|c|c|c|c|c|c|}
\hline \multirow{3}{*}{$\begin{array}{c}\text { TAZ-8B } \\
\text { alloy }\end{array}$} & \multirow{2}{*}{\multicolumn{11}{|c|}{ Composition, wt. $\%$}} \\
\hline & & & & & & & & & & & \\
\hline & $\mathrm{Ta}$ & $\mathrm{Cr}$ & $\mathrm{Al}$ & Mo & W & $\mathrm{Cb}$ & $\mathrm{Co}$ & $\mathrm{Zr}$ & $\mathrm{C}$ & B & $\mathrm{Ni}$ \\
\hline Nominal & 8 & 6 & 6 & 4 & 4 & 1.5 & 5 & 1 & 0.125 & 0.004 & Balance \\
\hline Typical heats & 8.22 & 5.73 & 5.44 & 4.05 & 3.80 & 1. 67 & 4.99 & 1.37 & 145 & 0034 & Balance \\
\hline & 8.07 & 5.60 & 5.27 & 3.94 & 3. 77 & 1. 55 & 5.00 & 1.18 & .071 & 0022 & Balance \\
\hline
\end{tabular}


polycrystalline material would be expected because the melting procedure was similar in each case.

\section{Melting, Casting, and Inspection Techniques}

Melts were made in 50-kilowatt, 10 000-cps (10 000-Hz) water-cooled induction units. A dual melting procedure was used. The initial melt was made under an inertgas (commercially pure argon) cover. The procedure was similar to that described in references 1 to 5 . Stabilized zirconia crucibles were used, and the pouring temperature as determined by an optical pyrometer was $3050^{\circ} \pm 50^{\circ} \mathrm{F}\left(1948^{\circ} \pm 28^{\circ} \mathrm{K}\right)$. Melts were poured without argon protection into copper molds at room temperature. The second stage of the dual melting procedure was to remelt the alloy under vacuum and pour it into zircon ceramic shell molds. Pouring temperature for the random polycrystalline material as determined by means of an optical pyrometer was $3100^{\circ}{ }_{ \pm} 50^{\circ} \mathrm{F}\left(1978^{\circ}{ }_{ \pm 2} 8^{\circ} \mathrm{K}\right)$. In casting the random polycrystalline material, the molds were preheated to $1600^{\circ} \mathrm{F}$ $\left(1144^{\circ} \mathrm{K}\right)$. A pressure of 10 microns $\left(1.33 \mathrm{~N} / \mathrm{m}^{2}\right)$ or less was maintained during melting and pouring.

In making the directionally solidified castings, the controlled solidification apparatus illustrated in figure 1 was used. The apparatus consists of a three-zone resistance mold heater which surrounds the shell mold. A reusable copper chill block extends into the lower part of the shell mold and establishes the orientation and growth direction of individual grains. Introduction of an appropriate power input to each zone of the heater provided a smooth temperature gradient in the vertical direction. Immediately prior to pouring (pour temperature $2900^{\circ} \pm 50^{\circ} \mathrm{F}\left(1867^{\circ} \pm 28^{\circ} \mathrm{K}\right)$, the temperature of the portion of the mold adjacent to the chill block was made approximately equal to the alloy melting temperature $\left(2450^{\circ} \mathrm{F}\left(1618^{\circ} \mathrm{K}\right)\right)$, and the temperature at the top of the mold was $2750^{\circ} \mathrm{F}$ $\left(1783^{\circ} \mathrm{K}\right)$. A lower pour temperature was used in casting the directionally solidified material in order to ensure that no leakage of the melt occurred at the interface between the chill block and the shell mold. Temperatures were determined by theromocouples located between the mold and the heater wall at intervals along the length of the mold. After pouring, power to the mold-heater zones was sequentially removed, and solidification proceeded vertically upward from the chill block.

All cast specimens were vapor blasted prior to inspection. All specimens were inspected by X-ray and by fluorescent-dye penetrant techniques before testing. Only defect-free bars were tested. 


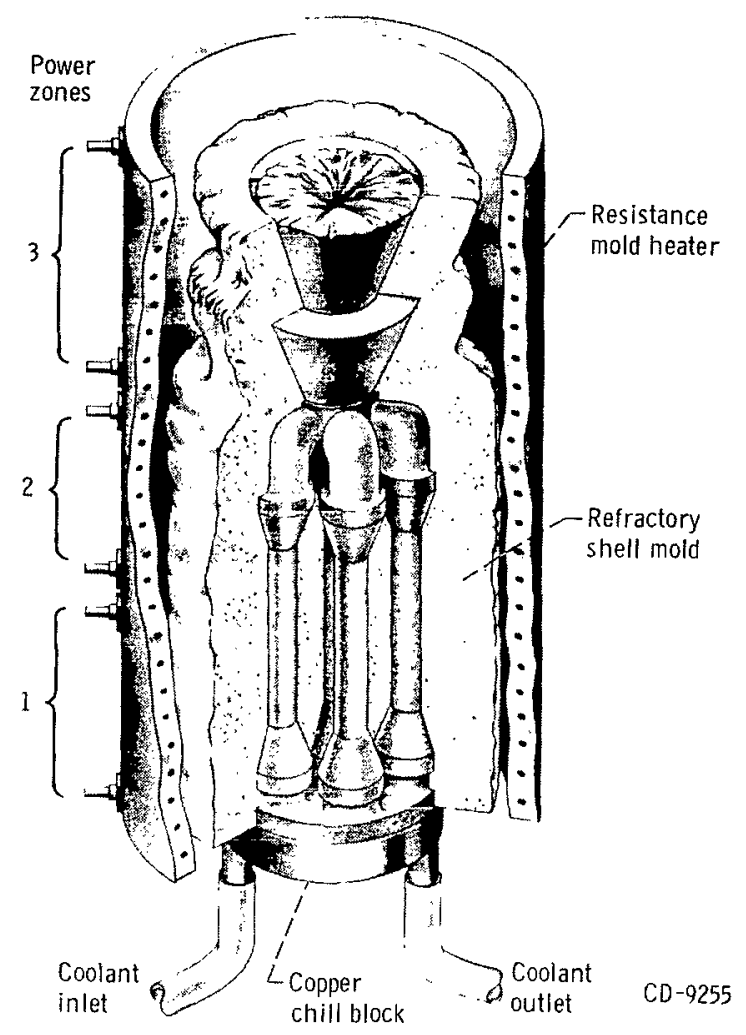

Figure 1. - Controlled solidification casting assembly.

\section{Specimens}

Random polycrystalline rupture and tensile bars were cast to final dimensions. The same type of specimen was used for both stress-rupture and tensile tests. These specimens had conical shoulders with a $20^{\circ}$ included angle. The gage section was 1.20 inches $(0.0305 \mathrm{~m})$ long and 0.25 inch $(0.00635 \mathrm{~m})$ in diameter. Directional polycrystalline bars were cast to the same initial size and subsequently etched to reveal grain structure. The test section was reduced by grinding to 0.240 -inch $(0.0061-\mathrm{m})$ diameter to remove the etched surface layer which could be detrimental to properties because of grain-boundary attack. The random polycrystalline material was tested in the vaporblasted condition because previous experience with this alloy series has shown that surface grinding has a negligible effect on properties. Charpy impact bars were cast slightly oversize and finish-machined to obtain the 0.394 by 0.394 inch $(0.010$ by $0.010 \mathrm{~m}$ ) ASTM standard cross-sectional dimensions. Blanks for investigating rollability were cast to dimensions of 3 by 5 by 0.15 inch $(0.076$ by 0.127 by $0.0038 \mathrm{~m})$. 


\section{Alloy Evaluation}

Stress-rupture and tensile tests. - All stress-rupture and tensile data were obtained in air. The specimens were tested in the as-cast condition without protective coatings. Tensile tests were also conducted at room temperature, $1200^{\circ} \mathrm{F}\left(922^{\circ} \mathrm{K}\right)$, and $1400^{\circ} \mathrm{F}$ $\left(1033^{\circ} \mathrm{K}\right)$ with test bars previously exposed for 1000 hours at $1600^{\circ} \mathrm{F}\left(1144^{\circ} \mathrm{K}\right)$ in air. The range of test conditions for stress-rupture tests was from $1800^{\circ}$ to $2100^{\circ} \mathrm{F}\left(1255^{\circ}\right.$ to $\left.1422^{\circ} \mathrm{K}\right)$ at $15000 \mathrm{psi}\left(103.4 \mathrm{MN} / \mathrm{m}^{2}\right)$ and from $1700^{\circ}$ to $1900^{\circ} \mathrm{F}\left(1200^{\circ}\right.$ to $\left.1311^{\circ} \mathrm{K}\right)$ at $25000 \mathrm{psi}\left(172.4 \mathrm{MN} / \mathrm{m}^{2}\right)$. Tensile tests were conducted over a range of temperatures from room temperature to $2200^{\circ} \mathrm{F}\left(1478^{\circ} \mathrm{K}\right)$.

Hardness. - Representative as-cast directionally solidified test specimens were sectioned transverse and parallel to the longitudinal axis. Rockwell $\mathrm{A}$ hardness readings were taken along each section. An average of five readings was taken as representative of the hardness in each direction. As-cast random polycrystalline specimens were sectioned transverse to the principal axis, and an average of five Rockwell $A$ readings across the section was taken as indicative of the hardness.

Impact tests. - A standard Charpy impact tester was used to measure impact resistance at room temperature. Both V-notched (ASTM type A) and unnotched specimens were tested.

Rolling. - Cast blanks of TAZ-8B were cut into three sections 1 by 5 by 0.15 inch $(0.025$ by 0.127 by $0.0038 \mathrm{~m}$ ). These sections were rolled into sheets approximately 0.020 inch $(0.0005 \mathrm{~m})$ thick. The blanks were rolled in one direction at $1900^{\circ} \mathrm{F}$ $\left(1311^{\circ} \mathrm{K}\right)$ in a conventional 2 -high mill at a surface speed of 80 feet per minute $(0.41$ $\mathrm{m} / \mathrm{sec})$. Reductions of 0.005 inch $(0.00013 \mathrm{~m})$ per pass, approximately 3 percent of the original thickness, were employed. Prior to each pass the blanks were heated to $1900^{\circ} \mathrm{F}\left(1311^{\circ} \mathrm{K}\right)$ in a protective (argon) atmosphere and transferred to the rolls as quickly as possible to minimize heat loss.

Metallographic studies. - Photomicrographs of TAZ-8B were made in both the random and directional polycrystalline forms. The crystal orientation of the columnar grain structure was determined by X-rays.

\section{PROPERTIES OF TAZ-8B}

\section{Tensile Data}

The tensile properties of $\mathrm{TAZ}-8 \mathrm{~B}$ in both the random and directional polycrystalline forms are summarized in table II and compared in figure 2 over a range of temperatures. The properties of TAZ-8A (ref. 7), the forerunner of TAZ-8B, are shown for 
TABLE II. - SUMMARY OF TENSILE DATA

\begin{tabular}{|c|c|c|c|c|c|c|c|}
\hline \multicolumn{2}{|c|}{ Temperature } & \multicolumn{3}{|c|}{ Random polycrystalline form } & \multicolumn{3}{|c|}{ Directional polycrystalline form } \\
\hline \multirow[t]{2}{*}{${ }^{o} F$} & \multirow{2}{*}{${ }^{0} \mathbf{K}$} & \multicolumn{2}{|c|}{ Ultimate tensile strength } & \multirow{2}{*}{$\begin{array}{c}\text { Elonga- } \\
\text { tion, } \\
\text { percent }\end{array}$} & \multicolumn{2}{|c|}{ Ultimate tensile strength } & \multirow{2}{*}{$\begin{array}{l}\text { Elonga- } \\
\text { tion, } \\
\text { percent }\end{array}$} \\
\hline & & psi & $\mathrm{MN} / \mathrm{m}^{2}$ & & psi & $\mathrm{MN} / \mathrm{m}^{2}$ & \\
\hline \multirow[t]{3}{*}{70} & 295 & 143. $7 \times 10^{3}$ & 991 & 5.0 & $153.7 \times 10^{3}$ & 1060 & 9.0 \\
\hline & & 142.0 & 979 & 3.0 & 152.2 & 1049 & 8.0 \\
\hline & - & $\mathrm{a}_{125.0}$ & $a_{862}$ & $\mathrm{a}_{2.5}$ & $a_{137.0}$ & $a_{945}$ & $a_{4.5}$ \\
\hline \multirow[t]{3}{*}{1200} & 922 & $152.5 \times 10^{3}$ & 1052 & 3.5 & $173.2 \times 10^{3}$ & 1194 & 6.0 \\
\hline & & 135.8 & 936 & 3.0 & 170.5 & 1176 & 6.0 \\
\hline & & $\mathrm{a}_{123.3}$ & $a_{850}$ & $a_{2.0}$ & $a_{163.2}$ & $a_{1125}$ & $a_{5.0}$ \\
\hline \multirow[t]{3}{*}{1400} & 1033 & $137.0 \times 10^{3}$ & 945 & 3.0 & $173.2 \times 10^{3}$ & 1194 & 4.0 \\
\hline & & 150.2 & 1036 & 3.0 & 171.3 & 1181 & 9.0 \\
\hline & & $a_{144.7}$ & ${ }^{a} 998$ & $\mathrm{a}_{2.0}$ & ${ }^{a} 157.8$ & ${ }^{a} 1088$ & $\mathrm{a}_{6.0}$ \\
\hline \multirow[t]{3}{*}{1600} & 1144 & 116. $0 \times 10^{3}$ & 800 & 3.0 & $125.8 \times 10^{3}$ & 867 & 12.5 \\
\hline & & 123.3 & 850 & 1.0 & 125.0 & 862 & 12. 0 \\
\hline & & 120.0 & 827 & 12.0 & & & \\
\hline \multirow[t]{2}{*}{1800} & 1255 & $79.6 \times 10^{3}$ & 549 & 4.0 & $80.5 \times 10^{3}$ & 555 & 16.0 \\
\hline & & 84.75 & 584 & 4.0 & 80.0 & 552 & 6.0 \\
\hline \multirow[t]{2}{*}{1900} & 1311 & $60.25 \times 10^{3}$ & 415 & 6.0 & ---------- & ---- & $\ldots-$ \\
\hline & & 63.1 & 435 & 8.0 & $----\cdots-\cdots$ & --- & --- \\
\hline \multirow[t]{2}{*}{2000} & 1366 & 41. $5 \times 10^{3}$ & 286 & 3.0 & $43.8 \times 10^{3}$ & 302 & 23.0 \\
\hline & & 42.4 & 292 & 4.0 & 41.8 & 288 & 21.0 \\
\hline \multirow[t]{2}{*}{2100} & 1422 & $30.0 \times 10^{3}$ & 207 & 6.0 & --------- & ---- & ---- \\
\hline & & 26.2 & 181 & 1.0 & 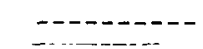 & --- & $-\cdots$ \\
\hline \multirow[t]{2}{*}{2200} & 1478 & 7. $66 \times 10^{3}$ & 53 & 2.0 & -------- & ---- & ---- \\
\hline & & 11.45 & 79 & 1. 0 & $-\cdots-\cdots$ & --- & --- \\
\hline
\end{tabular}

${ }^{\mathrm{a}}$ Prior exposure for $1000 \mathrm{hr}$ at $1600^{\circ} \mathrm{F}\left(1144^{\circ} \mathrm{K}\right)$. 


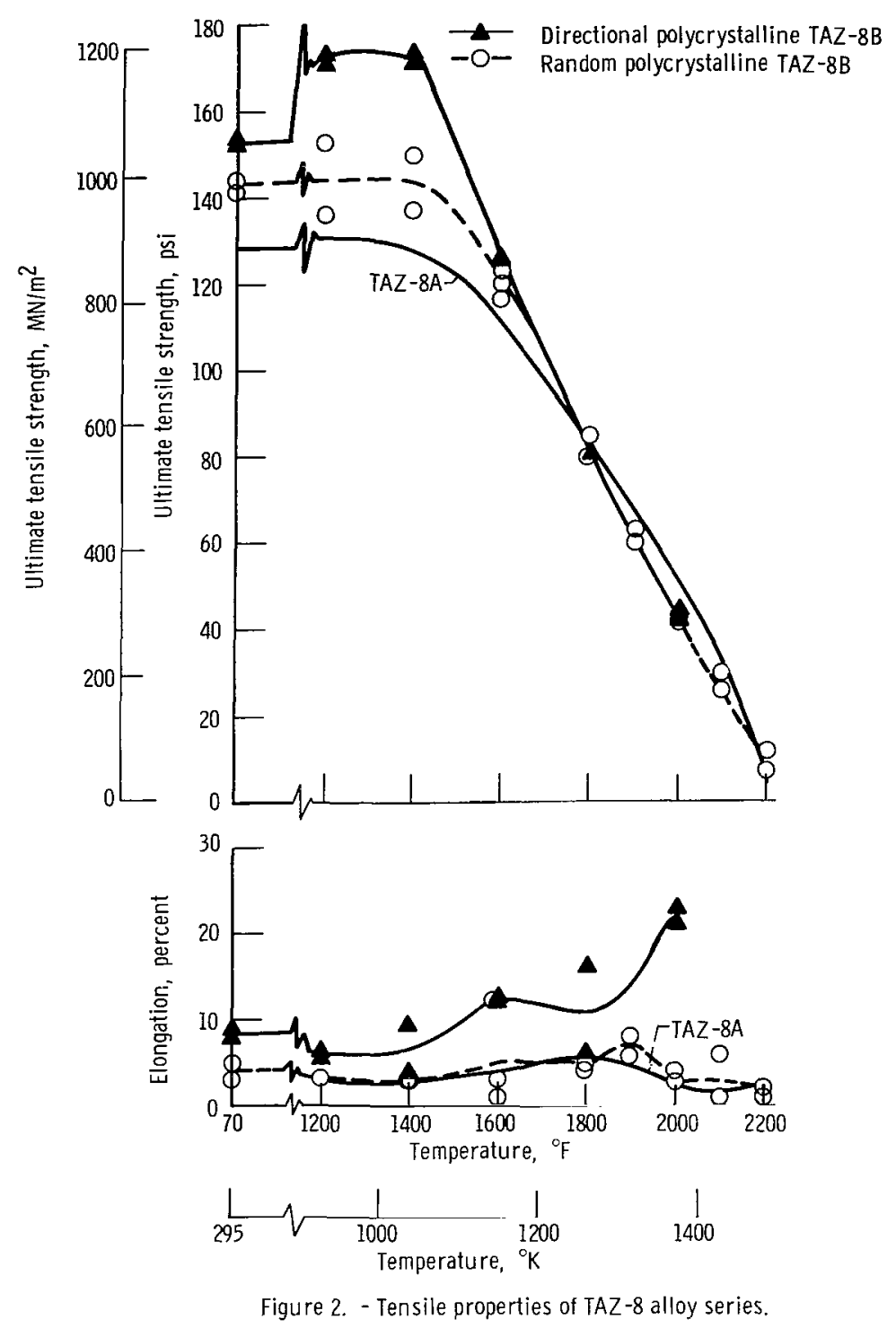

comparison. The directional polycrystalline material shows an improvement in tensile strength in the $1200^{\circ}$ to $1600^{\circ} \mathrm{F}\left(922^{\circ}\right.$ to $\left.1144^{\circ} \mathrm{K}\right)$ range over the random polycrystalline material. Above $1600^{\circ} \mathrm{F}\left(1144^{\circ} \mathrm{K}\right)$ the strength values are similar. At $1400^{\circ} \mathrm{F}$ $\left(1033^{\circ} \mathrm{K}\right)$, which is in a region of minimum ductility, directional solidification resulted in an increase in ultimate tensile strength from approximately 144000 to $172000 \mathrm{psi}$ (993 to $1185 \mathrm{MN} / \mathrm{m}^{2}$ ) and an elongation increase from 3 to 6 percent. Elongation is substantially higher for the directional polycrystalline material at all test temperatures and ranges from approximately 6 percent at $1200^{\circ} \mathrm{F}\left(922^{\circ} \mathrm{K}\right)$ to a maximum of 22 percent at $2000^{\circ} \mathrm{F}\left(1366^{\circ} \mathrm{K}\right)$.

A comparison of TAZ-8B and TAZ-8A shows the latter alloy to have substantially lower strength than either type of TAZ-8B to approximately $1800^{\circ} \mathrm{F}\left(1255^{\circ} \mathrm{K}\right)$ and 
slightly higher strength between $1800^{\circ}$ and $2200^{\circ} \mathrm{F}\left(1255^{\circ}\right.$ and $\left.1478^{\circ} \mathrm{K}\right)$. The maximum difference in strength occurs at $1400^{\circ} \mathrm{F}\left(1033^{\circ} \mathrm{K}\right)$ where TAZ-8A has an ultimate tensile strength of $128000 \mathrm{psi}\left(882 \mathrm{MN} / \mathrm{m}^{2}\right)$, random polycrystalline TAZ-8B, $144000 \mathrm{psi}$ $\left(993 \mathrm{MN} / \mathrm{m}^{2}\right)$, and directional polycrystalline TAZ-8B, $172000 \mathrm{psi}\left(1185 \mathrm{MN} / \mathrm{m}^{2}\right)$. At $2000^{\circ} \mathrm{F}\left(1366^{\circ} \mathrm{K}\right), \mathrm{TAZ}-8 \mathrm{~A}$ has an ultimate tensile strength of $50000 \mathrm{psi}\left(345 \mathrm{MN} / \mathrm{m}^{2}\right)$, random polycrystalline TAZ-8B, $42000 \mathrm{psi}\left(289 \mathrm{MN} / \mathrm{m}^{2}\right)$ and directional polycrystalline $\mathrm{TAZ}-8 \mathrm{~B}, 43000 \mathrm{psi}\left(296 \mathrm{MN} / \mathrm{m}^{2}\right)$.

The tensile elongation of random polycrystalline TAZ-8B was generally the same as that of TAZ-8A over the entire temperature range. The directional polycrystalline TAZ-8B, however, showed substantial increases in ductility over TAZ-8A at all test temperatures. These increases ranged from a factor of two at $1200^{\circ} \mathrm{F}\left(922^{\circ} \mathrm{K}\right)$ to more than five at $2000^{\circ} \mathrm{F}\left(1366^{\circ} \mathrm{K}\right)$.

\section{Stress-Rupture Data}

All the stress-rupture data are summarized in table III. Figure 3 illustrates the stress-rupture properties of TAZ-8B in the random and directional polycrystalline forms. For the most part, the directional polycrystalline material shows longer life. This improvement is significant at $1800^{\circ} \mathrm{F}\left(1255^{\circ} \mathrm{K}\right)$ and $15000 \mathrm{psi}\left(103.4 \mathrm{MN} / \mathrm{m}^{2}\right)$ (fig. 3(a)), where average life was increased approximately two-fold, from 800 to 1800 hours.

The effects of the two types of structure in TAZ-8B may also be compared on the basis of use temperature. At a stress of $15000 \mathrm{psi}\left(103.4 \mathrm{MN} / \mathrm{m}^{2}\right)$ the $1000-, 100-$, and 10-hour use temperatures are respectively, $1785^{\circ}, 1925^{\circ}$, and $2025^{\circ} \mathrm{F}\left(1247^{\circ}\right.$, $1325^{\circ}$, and $1380^{\circ} \mathrm{K}$ ) in the random polycrystalline form and $1830^{\circ}, 1940^{\circ}$, and $2040^{\circ} \mathrm{F}$ $\left(1272^{\circ}, 1333^{\circ}\right.$, and $\left.1389^{\circ} \mathrm{K}\right)$ in the directional polycrystalline form. The beneficial effect on life of the directionally oriented columnar grain structure tends to be reduced as temperatures increase. Similar trends were observed at a higher stress level. At $25000 \mathrm{psi}\left(172.4 \mathrm{MN} / \mathrm{m}^{2}\right.$ ) (fig. 3(b)), the directionally oriented material has approximately a two-fold life advantage at $1700^{\circ} \mathrm{F}\left(1200^{\circ} \mathrm{K}\right)$. This advantage is negligible at $1900^{\circ} \mathrm{F}\left(1311^{\circ} \mathrm{K}\right)$.

The progress that has been made in improving rupture life of the TAZ- 8 alloy series is shown in figure 4. The life for a stress of $15000 \mathrm{psi}\left(103.4 \mathrm{MN} / \mathrm{m}^{2}\right)$ at both $1800^{\circ}$ and $1900^{\circ} \mathrm{F}\left(1255^{\circ}\right.$ and $\left.1311^{\circ} \mathrm{K}\right)$ for directional polycrystalline $\mathrm{TAZ}-8 \mathrm{~B}$ is almost three times that of random polycrystalline TAZ-8A. At $2000^{\circ} \mathrm{F}\left(1366^{\circ} \mathrm{K}\right)$ and $15000 \mathrm{psi}$ $\left(103.4 \mathrm{MN} / \mathrm{m}^{2}\right)$, directional polycrystalline TAZ-8B has about twice the life of random polycrystalline TAZ-8A. 
TABLE III. - SUMMARY OF STRESS-RUPTURE DATA

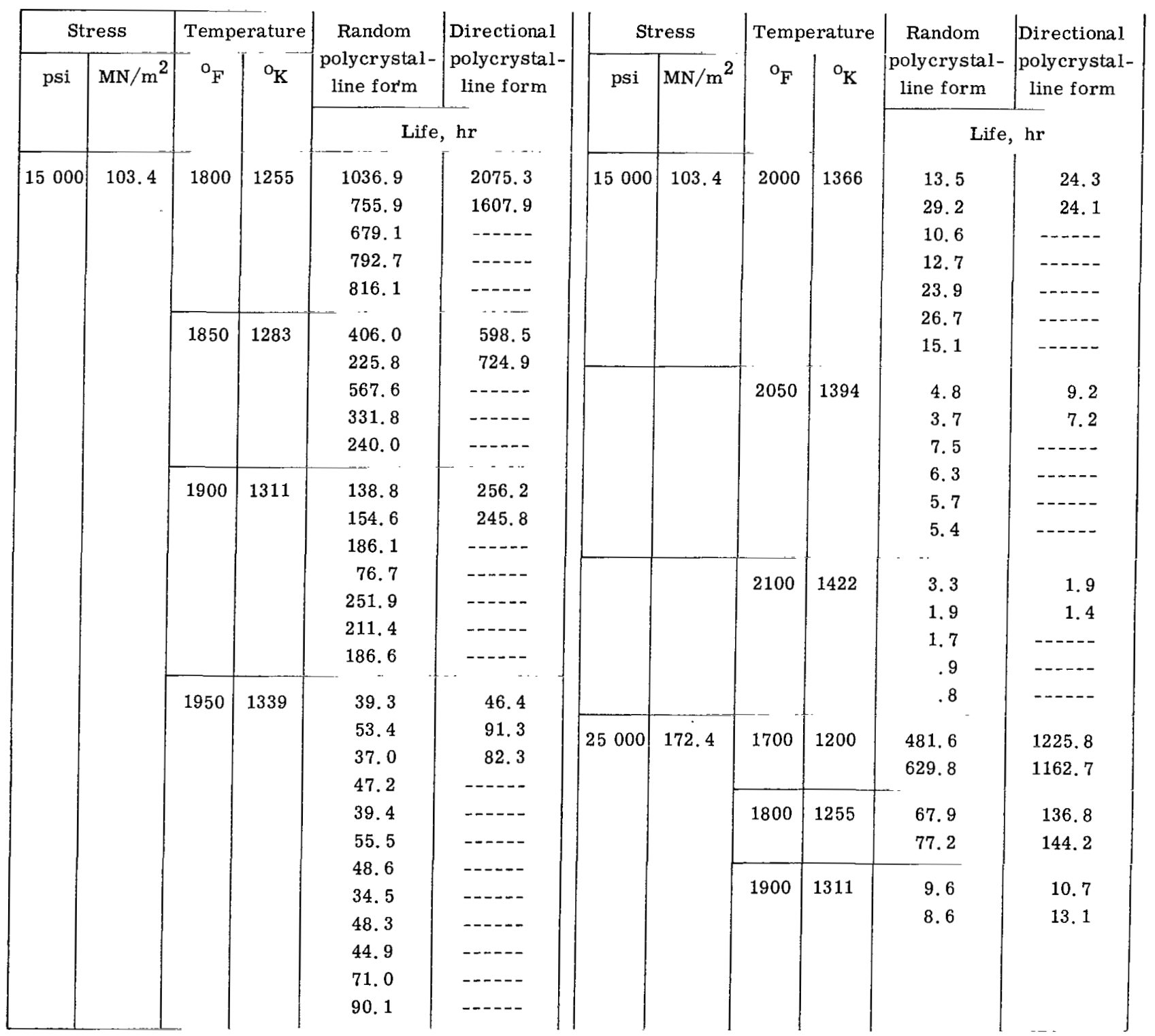




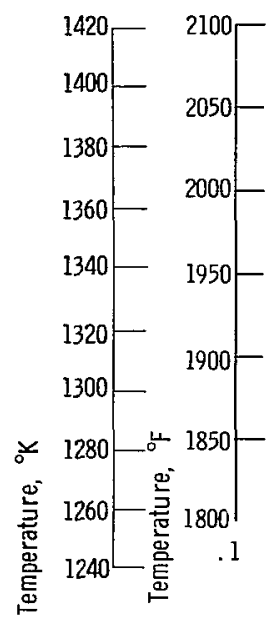

040 Directional polycrystalline TAZ-8B

O Random polycrystalline TAZ-8B

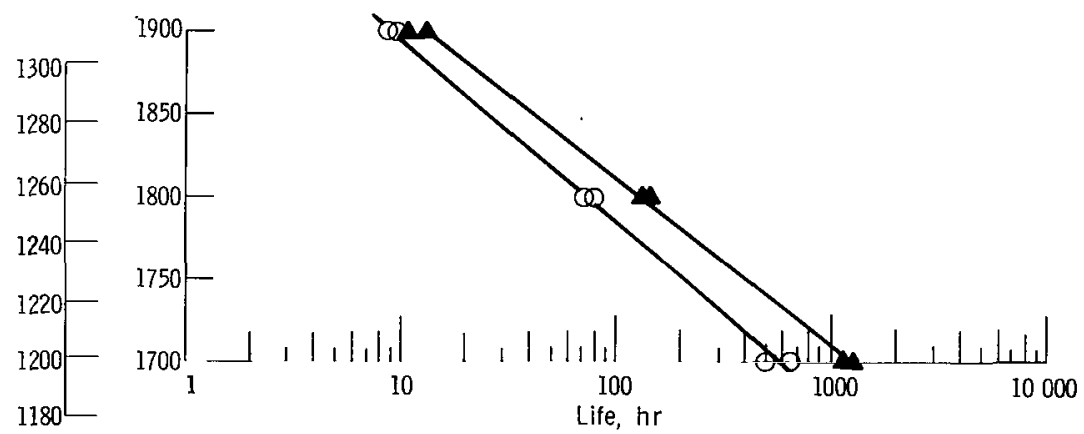

(b) Stress, $25000 \mathrm{psi}\left(172.4 \mathrm{MN} / \mathrm{m}^{2}\right)$.

Figure 3. - Comparison of stress-rupture properties of random and directional polycrystalline TAZ-8B.

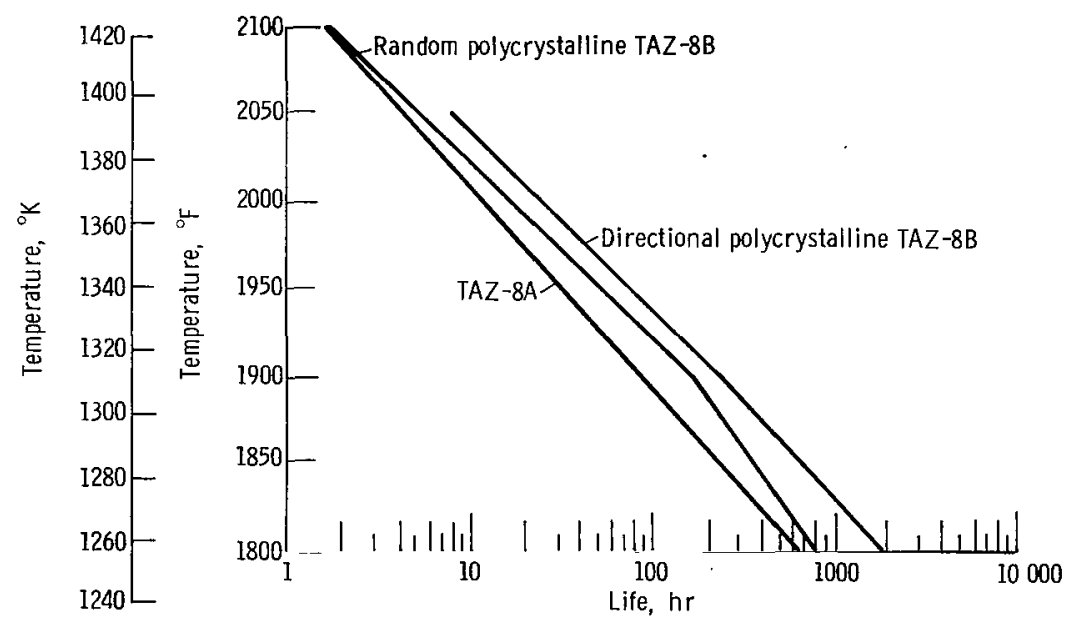

Figure 4. - Comparison of stress-rupture properties of TAZ-8 alloy series. Stress, $15000 \mathrm{psi}\left(103.4 \mathrm{MN} / \mathrm{m}^{2}\right)$. 


\section{Workability}

Workability potential of TAZ-8B in the random polycrystalline form was demonstrated by rolling cast slabs 0.15 inch $(0.0038 \mathrm{~m})$ thick at $1900^{\circ} \mathrm{F}\left(1311^{\circ} \mathrm{K}\right)$ into strips approximately 0.020 inch $(0.0005 \mathrm{~m})$ thick. No edge cracking of the sheet occurred during the rolling operation. The alloy has rollability characteristics similar to those of TAZ-8A (ref. 7). No attempt was made to optimize the rolling procedure. The techniques employed were essentially the same as those which proved to be acceptable for TAZ-8A. Also, no attempt was made to cast directionally solidified slabs for rolling evaluation.

Although the alloy was successfully rolled, it is not a wrought alloy in the conventional sense. It should be emphasized that the process of making sheet by rolling a thin cast slab is a somewhat specialized one. The fine grain size that can be obtained in a thin slab contributes to rollability of the alloy in that impurities that normally segregate at grain boundaries are more widely distributed. The results of this investigation suggest that the alloy may be worked under closely controlled conditions and thereby fulfill requirements that cannot normally be met by the usual wrought high-strength nickel-base alloys.

\section{Impact Resistance}

The Charpy impact resistance of $\mathrm{TAZ}-8 \mathrm{~B}$ in both the as-cast random polycrystalline and directional polycrystalline forms is shown in table IV. The unnotched Charpy im-

TABLE IV. - SUMMARY OF CHARPY IMPACT RESISTANCE DATA

\begin{tabular}{|c|c|c|c|c|c|c|c|c|}
\hline \multirow[t]{4}{*}{ Alloy } & \multicolumn{8}{|c|}{ Impact resistance } \\
\hline & \multicolumn{4}{|c|}{ Unnotched } & \multicolumn{4}{|c|}{$\mathrm{V}$-notched } \\
\hline & \multicolumn{2}{|c|}{ Measured values } & \multicolumn{2}{|c|}{ Average } & \multicolumn{2}{|c|}{ Measured values } & \multicolumn{2}{|c|}{ Average } \\
\hline & $\mathrm{ft}-\mathrm{lb}$ & $\mathrm{N}-\mathrm{m}$ & $\mathrm{ft}-\mathrm{lb}$ & $\mathrm{N}-\mathrm{m}$ & $\mathrm{ft}-\mathrm{lb}$ & $\mathrm{N}-\mathrm{m}$ & $\mathrm{ft}-\mathrm{lb}$ & $\mathrm{N}-\mathrm{m}$ \\
\hline \multicolumn{9}{|l|}{ TAZ-8B } \\
\hline Random & 42.0 & 57.0 & 40.0 & 54.0 & 6.0 & 8.1 & 6.2 & 8.5 \\
\hline polycrystalline & 38.0 & 51.5 & & & 6.5 & 8.8 & & \\
\hline Directional & 39.0 & 53.0 & 41.0 & 55.5 & 13.0 & 17.5 & 12.5 & 17.0 \\
\hline polycrystalline & 43.0 & 58.0 & & & 12.0 & 16.5 & & \\
\hline TAZ-8A & 19.0 & 26.0 & 24.0 & 33.0 & ---- & $-\cdots$ & ---- & --- \\
\hline & 20.0 & 27.0 & & & & & & \\
\hline & 34.0 & 46.0 & & & & & & \\
\hline
\end{tabular}


pact resistance of the random polycrystalline material was about the same as for the directional polycrystalline material, 40 foot-pounds ( $54 \mathrm{~N}-\mathrm{m}$ ) as compared with 41 footpounds $(55.5 \mathrm{~N}-\mathrm{m})$. The impact resistance of the notched directional polycrystalline material was twice that of the notched random polycrystalline material, 12.5 foot-pounds $(17 \mathrm{~N}-\mathrm{m})$ as compared to 6.2 foot-pounds $(8.5 . \mathrm{N}-\mathrm{m})$. The improved impact resistance is associated with the generally improved ductility of the directionally oriented material. It suggests that directionally solidified turbine blades made from this alloy would be more resistant to catastrophic failure from foreign-object damage than conventionally cast TAZ-8B.

\section{Hardness}

Rockwell A hardness values for TAZ-8B are listed in table V. For the random polycrystalline material, the average hardness was 71.8. For the directional polycrystalline material, average hardness along the longitudinal section was 71.7, and 71.8 along the transverse section. If a standard conversion table for steel is used, the average Rockwell A hardness values cited would be equivalent to Rockwell C values of approximately 42 to 43 . These data indicate that the grain orientation has essentially no effect on the macrohardness of TAZ-8B.

It is interesting that there was a negligible effect of prolonged exposure at $1600^{\circ} \mathrm{F}$ $\left(1144^{\circ} \mathrm{K}\right)$ on hardness. The random polycrystalline material had an average hardness of 71.4 after 1000 hours at $1600^{\circ} \mathrm{F}\left(1144^{\circ} \mathrm{K}\right)$. After a similar exposure, the average hardness of the directional polycrystalline material was 71. 5 .

TABLE V. - SUMMARY OF HARDNESS DATA

\begin{tabular}{|c|c|c|}
\hline \multirow[t]{2}{*}{ Form } & \multicolumn{2}{|c|}{ Rockwell A hardness } \\
\hline & $\begin{array}{c}\text { Range of } \\
\text { measured values }\end{array}$ & Average \\
\hline \multicolumn{3}{|c|}{ TAZ-8B (as cast) } \\
\hline Random polycrystalline & 71.3 to 72.1 & 71.8 \\
\hline Directional polycrystalline & & \\
\hline Transverse section & 71.1 to 72.3 & 71.8 \\
\hline Longitudinal section & 71.3 to 72.0 & 71.7 \\
\hline \multicolumn{3}{|c|}{$\begin{array}{c}\mathrm{TAZ}-8 \mathrm{~B} \text { exposed } 1000 \mathrm{hr} \text { at } 1600^{\circ} \mathrm{F}\left(1144^{\circ} \mathrm{K}\right) ; \\
\text { transverse section }\end{array}$} \\
\hline Random polycrystalline & 71.0 to 71.8 & 71.4 \\
\hline Directional polycrystalline & 71.2 to 71.7 & 71.5 \\
\hline
\end{tabular}




\section{Microstructural Stability}

Service requirements for nickel-base alloys in gas turbine applications include long exposure times of the order of several thousands of hours at temperature. Such exposure can alter the phases present as well as their morphology. Formation of the sigma phase after long service exposure in the $1450^{\circ}$ to $1700^{\circ} \mathrm{F}\left(1061^{\circ}\right.$ to $\left.1200^{\circ} \mathrm{K}\right)$ temperature range has been observed in some advanced high-strength, high-temperature nickel-base alloys (ref. 11). The formation of this phase can significantly reduce tensile ductility and decrease creep-rupture life.

It has been shown (ref. 12) that it is possible to predict with reasonable accuracy whether or not an alloy will form sigma phase by calculating the electron-vacancy concentration $\overline{\mathbf{N}}_{\mathbf{v}}$ of the residual matrix after other phases such as gamma-prime $\left(\gamma^{\prime}\right)$ and the carbides have precipitated. Various assumptions must be made as to the manner in which the elements present in the alloy are partitioned in forming the carbides, borides, and the gamma-prime phase. The amounts of the various elements remaining after such phase formation, scaled to 100, are equivalent to the residual matrix composition. Electron-vacancy numbers are assigned to each element. The average electron-vacancy number $\overline{\mathrm{N}}_{\mathrm{v}}$ of the residual matrix is then determined by summing the products of the atomic fraction of each element times its electron-vacancy number. If the calculated average electron-vacancy number is below the cutoff point for stability as determined from experimental data for representative nickel-base alloys, sigma phase would not be expected to form.

The $\overline{\mathrm{N}}_{\mathrm{V}}$ for TAZ-8B was calculated to be 2.27 according to assumptions similar to those of method $\overline{\mathrm{N}}_{\mathrm{v}, 9}$ (ref. 13). In calculating $\overline{\mathrm{N}}_{\mathrm{v}}$ by this method, it was assumed that half the carbon forms $\mathrm{MC}$ carbides and half forms $\mathbf{M}_{6} \mathrm{C}$. The gamma-prime composition is given by the following expression:

$$
\mathrm{N}_{2.95}(\mathrm{Mo}+\mathrm{W})_{0.05}(\mathrm{Al}, \mathrm{Ti}, \mathrm{Ta}, \mathrm{Cb}, \mathrm{Zr}, 0.5 \mathrm{~V}, 0.3 \mathrm{Cr})
$$

where $\mathrm{Cr}$ is the original atomic percent of $\mathrm{Cr}$ in the alloy and the amounts of the other elements have been reduced by the formation of borides and carbides. On the basis of these calculations, TAZ-8B would be expected to be sigma-free since the safe upper limit for $\overline{\mathrm{N}}_{\mathrm{v}}$ appears to be 2.59 (ref. 13). Although TAZ-8A is also predicted to be sigma free by this method $\left(\bar{N}_{v}, 2.26\right)$, there is some evidence that the mu phase, which can cause embrittlement, may occur in this alloy (private communication from Dr. J. Radavich, Micro-Met Labs Inc., West LaFayette, Ind.). The similarity in composition between TAZ-8A and TAZ-8B suggests that the latter alloy may form the mu phase.

In addition to predicting the possibility of sigma phase formation by electronvacancy-number calculations, tensile data were obtained to determine if embrittlement 
TABLE VI. - EFFECTS OF 1000-HOUR EXPOSURE IN AIR AT $1600^{\circ} \mathrm{F}$

$\left(1144^{\circ} \mathrm{K}\right)$ ON TENSILE PROPERTIES OF TAZ-8B

\begin{tabular}{|c|c|c|c|c|c|c|c|c|}
\hline \multirow[t]{4}{*}{ TAZ-8B alloy form } & \multirow{2}{*}{\multicolumn{2}{|c|}{$\begin{array}{c}\text { Test } \\
\text { temperature }\end{array}$}} & \multicolumn{4}{|c|}{ Ultimate tensile strength } & \multicolumn{2}{|c|}{ Elongation, percent } \\
\hline & & & psi & $\mathrm{MN} / \mathrm{m}^{2}$ & psi & $\mathrm{MN} / \mathrm{m}^{2}$ & \multirow{3}{*}{$\begin{array}{l}\text { Unexposed } \\
\text { (as cast) }\end{array}$} & \multirow{3}{*}{ Exposed } \\
\hline & ${ }^{o} \mathrm{~F}$ & ${ }^{\mathrm{o}} \mathrm{K}$ & & & & & & \\
\hline & & & \multicolumn{2}{|c|}{$\begin{array}{l}\text { Unexposed } \\
\text { (as cast) }\end{array}$} & \multicolumn{2}{|c|}{ Exposed } & & \\
\hline \multirow{3}{*}{$\begin{array}{l}\text { Random } \\
\text { polycrystalline }\end{array}$} & 70 & 295 & $143.0 \times 10^{3}$ & 986 & $125.0 \times 10^{3}$ & 862 & 4.0 & 2. 5 \\
\hline & 1200 & 922 & 144.0 & 993 & 123.2 & 849 & 3.3 & 2. 0 \\
\hline & 1400 & 1033 & 143.6 & 990 & 144.7 & 998 & 3.3 & 2.0 \\
\hline \multirow{3}{*}{$\begin{array}{l}\text { Directional } \\
\text { polycrystalline }\end{array}$} & 70 & 295 & $153.0 \times 10^{3}$ & 1055 & $137.0 \times 10^{3}$ & 945 & 8.5 & 4.5 \\
\hline & 1200 & 922 & 171.8 & 1185 & 163.2 & 1125 & 6.0 & 5.0 \\
\hline & 1400 & 1033 & 172.2 & 1187 & 157.8 & 1088 & 6.5 & 6.0 \\
\hline
\end{tabular}

occurred. Tensile tests were made with specimens of the alloy in both the random and directional polycrystalline forms after they had been exposed for 1000 hours at $1600^{\circ} \mathrm{F}$ $\left(1144^{\circ} \mathrm{K}\right)$. The microstructures after such exposure are described in a subsequent section on metallography. Table VI shows the ultimate tensile strength and percent elongation values obtained after exposure compared with those in the as-cast condition. In general, small decreases in elongation were observed after exposure for both the random and the directional polycrystalline materials. The drop in ductility suggests that despite its low electron-vacancy number the alloy is probably slightly unstable after long exposure. This effect is less deleterious in the directional polycrystalline form than in the random polycrystalline form. Thus, the lowest ductility obtained from the exposed directionally solidified material (4.5 percent at room temperature) was greater than the highest ductility obtained from unexposed random polycrystalline material (4 percent at room temperature). It is possible that the instability reflected by these data resulted from a reaction other than sigma formation, such as precipitation of carbides of mu phase formation.

\section{Oxidation Resistance}

The alloy was not subjected to conventional oxidation tests, and, thus, oxidation rates were not determined. However, visual examination of tested stress-rupture specimens and the specimens exposed for 1000 hours at $1600^{\circ} \mathrm{F}\left(1144^{\circ} \mathrm{K}\right)$ for stability studies indicated that the oxidation resistance of TAZ-8B was good. On a qualitative basis, its oxidation resistance is comparable to that of TAZ-8A. For the limited number of directional polycrystalline and random polycrystalline specimens that were directly 
comparable, there was no noticeable differ ence in oxidation resistance. However, the exact effect of directional solidification on the oxidation resistance of $\mathrm{TAZ}-8 \mathrm{~B}$ remains to be investigated.

\section{Metallography}

Macrographs of a directionally solidified tensile test bar of TAZ-8B are shown in figure 5. The grains are columnar and extend along the length of the bar. The macrograph of figure $5(\mathrm{~b})$ is a magnified view of a transverse section of the test bar. Many individual grains can be distinguished. An X-ray diffractometer pattern taken from the end of a directionally solidified test bar showed that the reflections from (100) planes were substantially enhanced. This result indicated a high degree of orientation of the [100] direction perpendicular to the chill.

Directional polycrystalline TAZ-8B in the as-cast condition is shown at a magnification of 250 in figure 6. Although grain boundaries were evident at low magnification, they were not apparent at a magnification of 250. Both the sections parallel and perpendicular to the growth direction show the same general features: a matrix containing a finely dispersed gamma-prime precipitate and large primary gamma-prime nodules (large white particles). A few carbides or carbonitrides (small angular-shaped white particles) are present. The latter were more easily observed in unetched specimens. Figure 7 shows that the random polycrystalline and directional polycrystalline structures are similar on a microscale. At a magnification of 750 the gamma-prime precipitate in the matrix was clearly resolved.

The microstructures of TAZ-8B in both the random and dir ectional polycrystalline forms after exposure for 1000 hours at $1600^{\circ} \mathrm{F}\left(1144^{\circ} \mathrm{K}\right)$ are shown in figure 8 . No embrittling acicular phase was observed in either sample. There was no evidence of agglomeration of the gamma-prime phase.

The microstructure of as-rolled, TAZ-8B, 0.020-inch $(0.0005-\mathrm{m})$ sheet is illustrated in figure 9 at a magnification of 250. The section shown is parallel to the rolling direction. The massive primary gamma-prime particles prevalent throughout the ascast structure as well as the carbides have been markedly deformed in the rolling direction. The microstructure has clearly been refined by rolling as compared with the ascast material, and there is no evidence of recrystallization. 


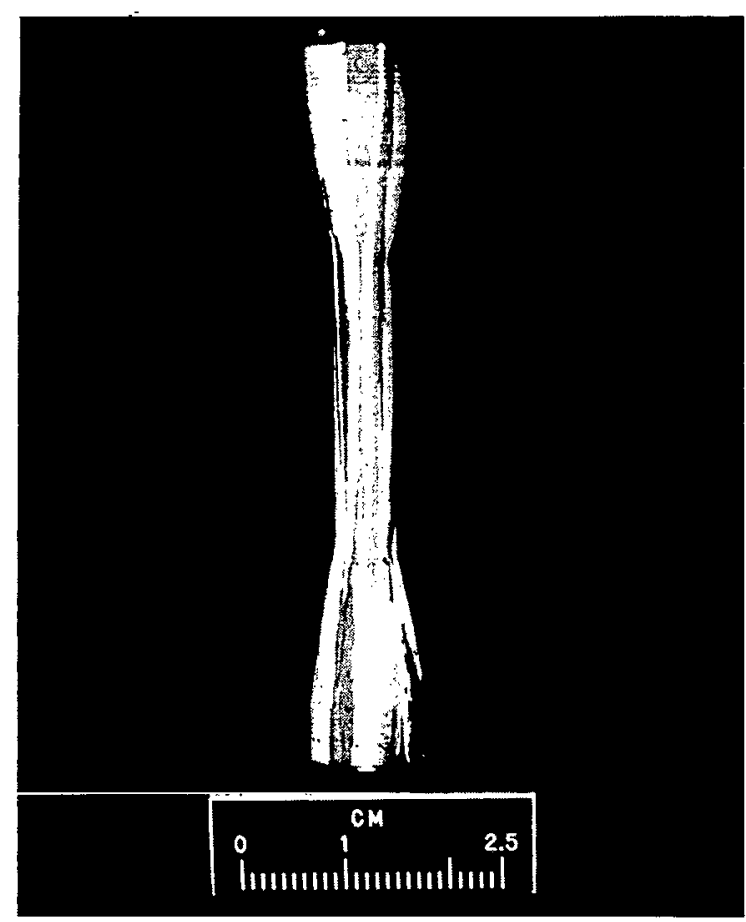

(a) Parallel to crystal growth direction.

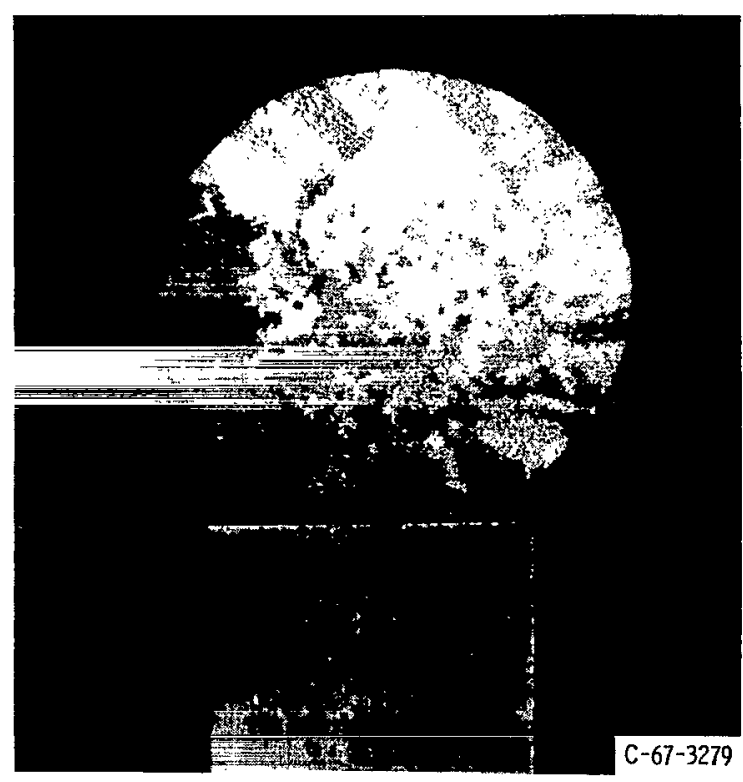

(b) Perpendicular to crystal growth direction.

Figure 5. - Macrographs of directionally solidified TAZ-8B test specimen. Etchant, 95 percent hydrochloric acid and 5 percent hydrogen peroxide.

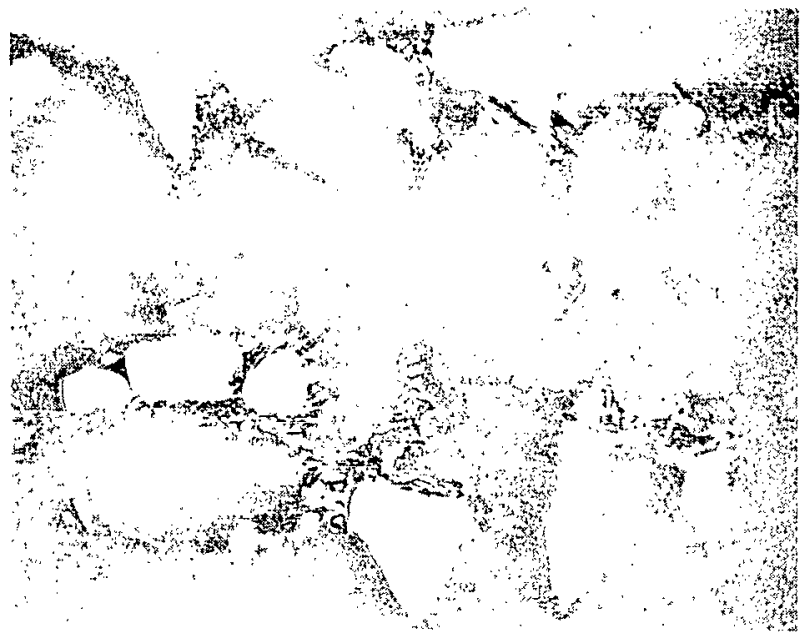

(a) Parallel to crystal growth direction.

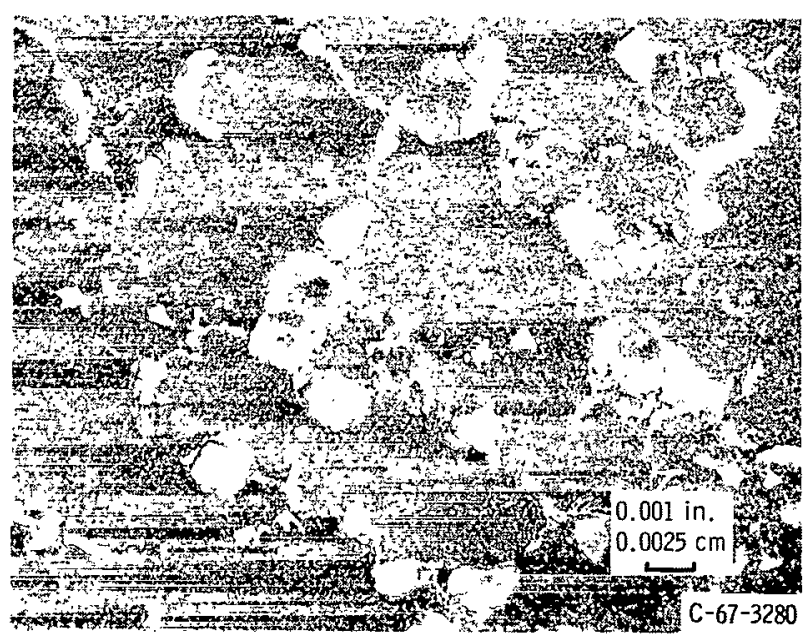

(b) Perpendicular to crystal growth direction.

Figure 6. - Micrographs of directional polycrystalline TAZ-8B as cast. Etchant, 36.5 percent water, 36.5 percent glycerine, 18 percent nitric acid, and 9 percent hydrofluoric acid (electrolytic). X250. 


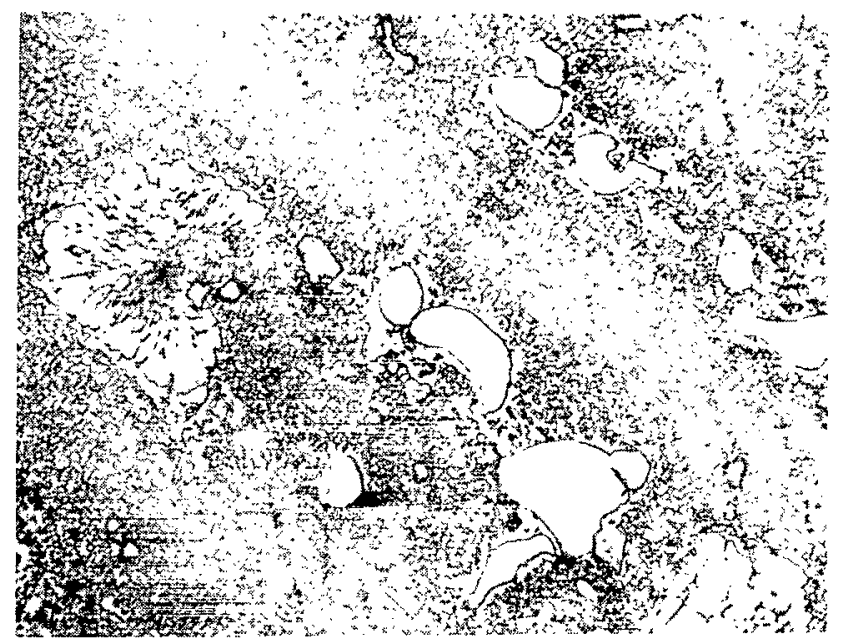

(a) Random polycrystalline.

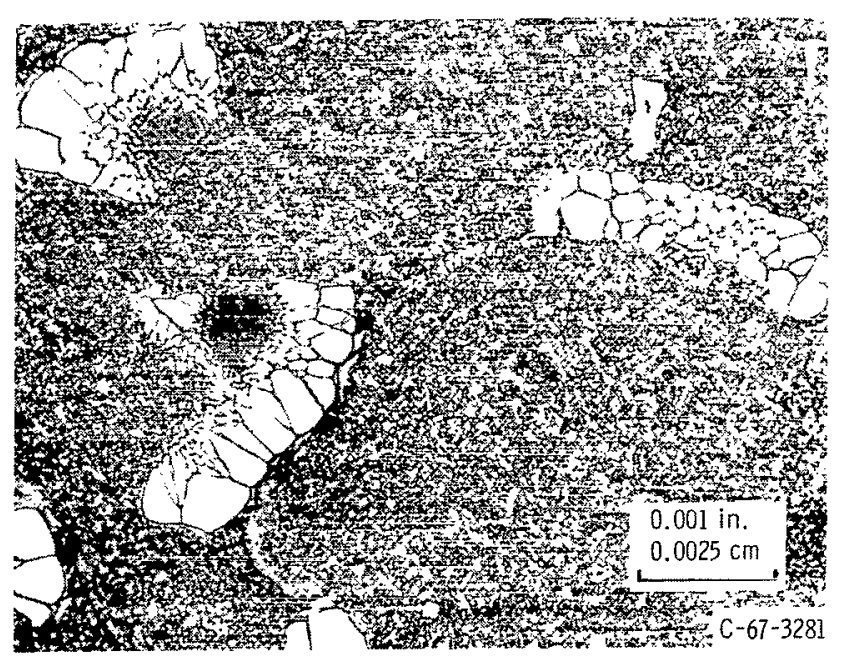

(b) Directional polycrystalline.

Figure 7. - Micrographs of random and directional polycrystalline TAZ-8B as cast. Specimens taken perpendicular to tensile specimen axis. Etchant, 36.5 percent water, 36.5 percent glycerine, 18 percent nitric acid, and 9 percent hydrofluoric acid (electrolytic). X750.

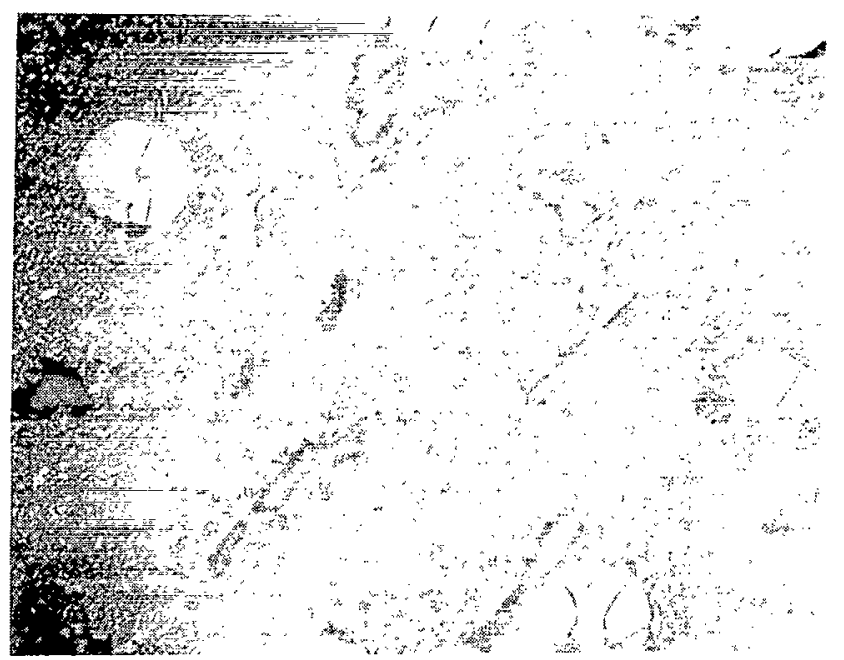

(a) Random polyerystalline.

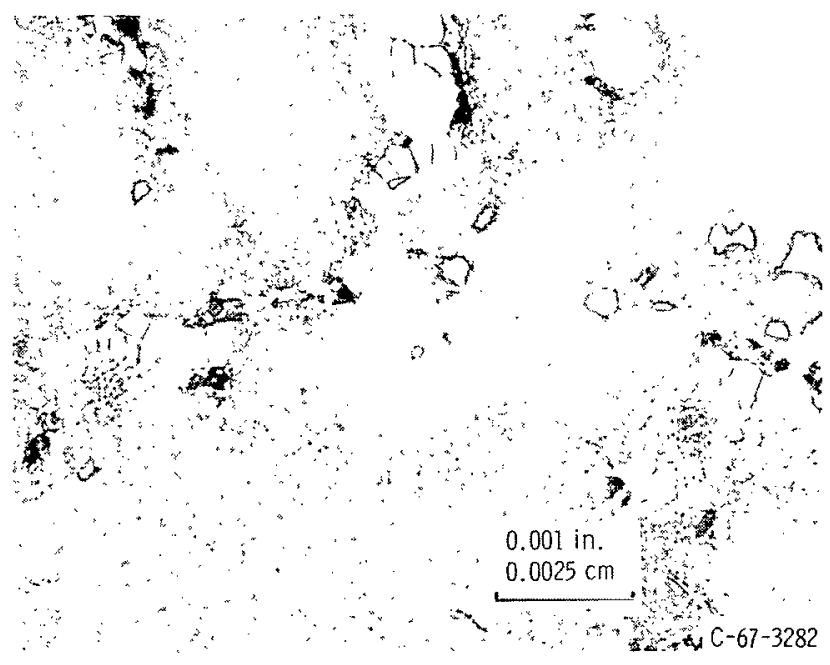

(b) Directional polycrystalline.

Figure 8. - Micrographs of random and directional polycrystalline TAZ-8B after exposure for 1000 hours at $1600^{\circ} \mathrm{F}\left(1144^{\circ} \mathrm{K}\right)$. Sections taken perpendicular to tensile specimen axis. Etchant, 36.5 percent water, 36.5 percent glycerine, 18 percent nitric acid, and 9 percent hydrofluoric acid (electrolytic). X750. 


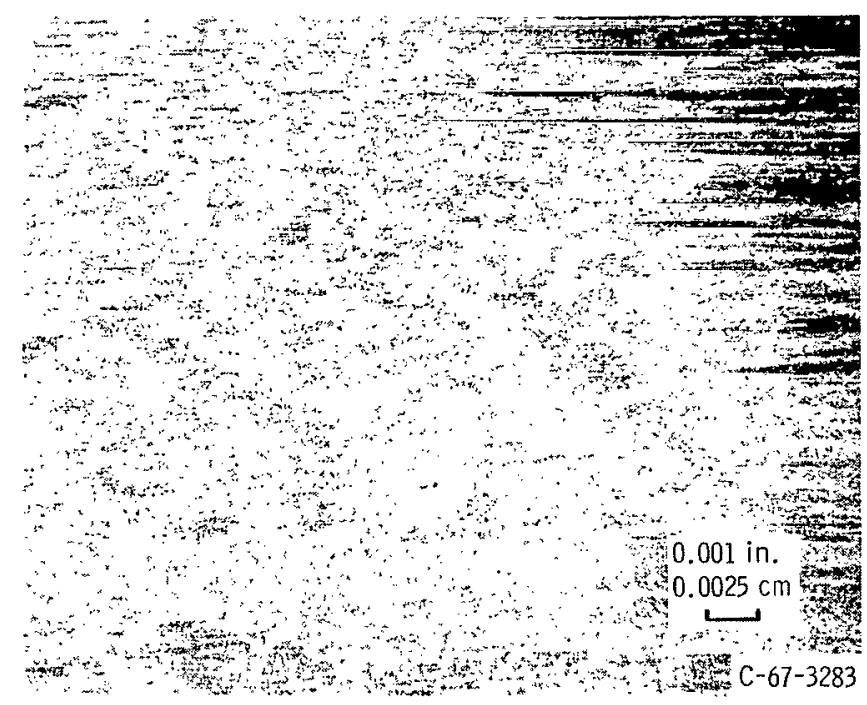

Figure 9. - Microstructure of hot-rolled 0.020-inch (0.0005-m) TAZ-8B alloy sheet. Etchant, 36.5 percent water, 36.5 percent glycerine, 18 percent nitric acid, and 9 percent hydrofluoric acid (electrolytic). $\mathrm{X} 250$.

\section{CONCLUDING REMARKS}

It has been demonstrated that directional solidification techniques can be usefully applied to the TAZ-8B alloy. The improved properties obtained as a result of the oriented columnar grain structure enhance the potential of the alloy for application to turbomachinery components.

\section{SUMMIARY OF RESULTS}

From this investigation to provide a nickel-base alloy with improved hightemperature capability for gas-turbine and other elevated-temperature applications, the following results were obtained:

1. A high-strength nickel-base alloy (TAZ-8B) was developed. Its nominal composition in weight percent is 1.5 columbium, 8 tantalum, 6 chromium, 6 aluminum, 4 molybdenum, 4 tungsten, 5 cobalt, 1 zirconium, 0.125 carbon, 0.004 boron, and the balance nickel.

2. The application of directional solidification techniques to the alloy resulted in substantial increases in intermediate-temperature $\left(1200^{\circ}\right.$ to $1600^{\circ} \mathrm{F}\left(922^{\circ}\right.$ to $\left.\left.1144^{\circ} \mathrm{K}\right)\right)$ tensile strength, substantially improved ductility over the entire temperature range studied $\left(1200^{\circ}\right.$ to $2200^{\circ} \mathrm{F}\left(922^{\circ}\right.$ to $\left.\left.1478^{\circ} \mathrm{K}\right)\right)$, and generally increased stress-rupture life. For example, at $1400^{\circ} \mathrm{F}\left(1033^{\circ} \mathrm{K}\right)$ the tensile strength and elongation of the direc- 
tional polycrystalline TAZ-8B were $172000 \mathrm{psi}\left(1185 \mathrm{MN} / \mathrm{m}^{2}\right)$ and 6 percent, respectively, compared with $144000 \mathrm{psi}\left(993 \mathrm{MN} / \mathrm{m}^{2}\right)$ and 3 percent for random polycrystalline TAZ-8B. At a stress of $15000 \mathrm{psi}\left(103.4 \mathrm{MN} / \mathrm{m}^{2}\right)$ the $1000-, 100-$, and 10 -hour use temperatures for the random polycrystalline material are $1785^{\circ}, 1925^{\circ}$, and $2025^{\circ} \mathrm{F}$ $\left(1247^{\circ}, 1325^{\circ}\right.$, and $\left.1380^{\circ} \mathrm{K}\right)$, respectively, and for the directional polycrystalline material they are $1830^{\circ}, 1940^{\circ}$, and $2040^{\circ} \mathrm{F}\left(1272^{\circ}, 1333^{\circ}\right.$, and $\left.1389^{\circ} \mathrm{K}\right)$.

3. TAZ-8B was hot-rolled from random polycrystalline cast slabs 0.15 inch $(0.0038 \mathrm{~m})$ thick to a thickness of approximately 0.020 inch $(0.0005 \mathrm{~m})$ in a conventional rolling mill. The reduction obtained indicates the alloy has at least limited workability potential.

4. The alloy exhibits good room-temperature impact resistance in the unnotched condition. The average unnotched impact resistance was 40 and 41 foot-pounds (54 and $55.5 \mathrm{~N}-\mathrm{m}$ ) for the random polycrystalline and directional polycrystalline materials, respectively. In the notched condition, impact resistance was improved two-fold by directional solidification. The directional polycrystalline material had a notched impact resistance of 12.5 foot-pounds $(17 \mathrm{~N}-\mathrm{m})$ as compared with 6.2 foot-pounds $(8.5 \mathrm{~N}-\mathrm{m})$ for the random polycrystalline material.

5. On the basis of calculated electron-vacancy number, TAZ-8B would not be expected to form sigma phase.

6. Only minor decreases in $1400^{\circ} \mathrm{F}\left(1033^{\circ} \mathrm{K}\right)$ ductility were observed after exposure for 1000 hours at $1600^{\circ} \mathrm{F}\left(1144^{\circ} \mathrm{K}\right)$. In the random polycrystalline material tensile elongation decreased from 3.3 percent before exposure to 2.0 percent after exposure and in the directional polycrystalline material from 6.5 to 6 percent. However, the decreases noted suggest that some type of instability may occur in this alloy with aging.

Lewis Research Center,

National Aeronautics and Space Administration, Cleveland, Ohio, November 9, 1967, 129-03-01-03-22.

\section{REFERENCES}

1. Freche, John C. ; and Waters, William J.: Exploratory Investigation of AdvancedTemperature Nickel-Base Alloys. NASA Memo 4-13-59E, 1959.

2. Freche, John C.; Riley, Thomas J.; and Waters, William J.: Continued Sudy of Advanced-Temperature Nickel-Base Alloys to Investigate Vanadium Additives. NASA TN D-260, 1960. 
3. Freche, John C.; Waters, William J.; and Riley, Thomas J.: A New Series of Nickel-Base Alloys for Advanced-Temperature Applications. Trans. ASM, vol. 53, 1961, pp. 523-537.

4. Freche, John C.; Waters, William J.; and Riley, Thomas J. : A New Series of Advanced-Temperature Nickel-Base Alloys. High Temperature Materials - II. G. M. Ault, W. F. Barclay and H. P. Munger, eds., Interscience Publ., 1963, pp. 215-228.

5. Freche, John C. ; and Waters, William J. : Continued Investigation of an AdvancedTemperature, Tantalum-Modified, Nickel-Base Alloy. NASA TN D-1531, 1963.

6. Freche, John C.: Progress in Superalloys. NASA TN D-2495, 1964.

7. Waters, William J.; and Freche, John C.: Investigation of Columbium-Modified NASA TAZ-8 Superalloy. NASA TN D-3597, 1966.

8. Lund, C. H. : Physical Metallurgy of Nickel-Base Superalloys. DMIC Rep. 153, Battelle Memorial Institute, May 5, 1961.

9. VerSnyder, F. L. ; and Guard, R. W.: Directional Grain Structures for HighTemperature, Strength. Trans. ASM, vol. 52, 1960, pp. 485-493.

10. Piearcey, B. J. ; and VerSnyder, F. L.: New Casting Technique Strengthens Turbine Components. SAE J., vol. 74, no. 6, June 1966, pp. 84-87.

11. Wile, George J.: Materials Considerations for Long Life Jet Engines. Paper No. 660057, SAE, Jan. 1966.

12. Woodyatt, L. R.; Sims, C. T.; and Beattie, H. J., Jr.: Prediction of Sigma-Type Phase Occurrence from Compositions in Austentic Superalloys. Trans. AIME, vol. 236, no. 4, Apr. 1966, pp. 519-527.

13. Collins, H. E. : Research on Microstructural Instability of Nickel-Base Superalloys. Interim Eng. Prog. Rep. No. 3, (Contract AF 33(615)-5126), TRW, Inc., Apr., 1967. 